Student Success

ISSN: 2205-0795

Volume 10, Issue 2, pp. 35-45

August 2019

\title{
International students' transition to university: Connection and disconnection in online group work interactions*
}

\author{
Jade Sleeman, Catherine Lang and Eva Dakich
}

La Trobe University, Melbourne, Australia

\begin{abstract}
An Australian higher education experience often includes group work as an important social learning opportunity. For international students, taking part in a group assignment can positively influence learning and adjustment to the new cultural and educational context through social interaction. However, students are increasingly choosing to use digital technologies to participate in group assignments, which may impact on opportunities available to make social connections with peers. This study investigated the experiences of 26 international students as they transitioned to study at an Australian university about their use of social media for group assignments and their resulting perceptions of connection to classmates. Analysis of the results suggests that students who engaged in collaborative rather than cooperative interactions via social media were more likely to perceive a connection to their classmates. This has implications for educators to include classroom modelling of digitally-mediated collaborative interactions to benefit students' participation in group assignments, which can improve the transition experience through social connection.
\end{abstract}

*This article was presented at the STARS Conference in Melbourne, Australia in July 2019 and was selected for publication in this special issue. The authors have kindly given their permission to have this article published and it has undergone a further review by the editors to confirm it aligns with the Journal's submission guidelines and standards.

Please cite this article as:

Sleeman J., Lang, C., \& Dakich, E. (2019). International students' transition to university: Connection and disconnection in online group work interactions. Student Success, 10(2). 35-45. doi:10.5204/ssj.v10i2.1300.

This article has been peer reviewed and accepted for publication in Student Success. Please see the Editorial Policies under the 'About' section of the Journal website for further information.

Student Success: A journal exploring the experiences of students in tertiary education

(x) $(6)$ This work is licensed under a Creative Commons Attribution 4.0 International Licence. As an open access journal, articles are free to use with proper attribution. ISSN: 2205-0795 


\section{Introduction}

Group assignments are popularly used in higher education courses to facilitate social learning interactions among students. While these interactions can have advantages for learning, they can also provide students with opportunities to make social connections that can increase engagement (Zhao \& Kuh, 2004). These social connections are important for all students in making a successful transition to university, but for international students, the social element of learning can also facilitate academic adjustment through language and cultural learning (Cruickshank, Chen, \& Warren, 2012). Where group assignments would once have entailed face-to-face interaction, they are now often conducted using digital technologies, such as social network sites (SNSs) (Henderson, Selwyn, Finger, \& Aston, 2015). For this reason, this study investigated the digitally-mediated experiences of international students in group assignment situations, and their resulting perceptions of connections to classmates.

\section{Background}

Educational research has investigated how to organise formal learning experiences in groups to extend an individual's ability through coconstruction of knowledge, as well as facilitate social interaction within the classroom. The literature abounds with various terms such as 'peer learning', 'group work', 'cooperative' or 'collaborative learning', and 'learning communities', but it is the concept of learning in groups to bridge the gap between academic and social life which is key to student engagement (Tinto, 1997).

Early research on organised group learning was very much concerned with an outcomes or effects focus (Dillenbourg, Baker, Blaye, \& O'Malley, 1996; Janssen, Kirschner, Erkens, Kirschner, \& Paas, 2010). In meta-analyses of studies on group learning, social learning interactions are promoted as beneficial for problem-solving, achievement, motivation and social relationships (Johnson \& Johnson, 2009). However, research studies on group learning that focused only on the outcomes and not on the processes involved in group interactions faced criticism because of a lack of attention to variables that may influence the learning outcomes through group dynamics (Dillenbourg et al., 1996). Thus, research now takes a more process-oriented approach to investigating social learning interactions. One important finding from this approach are the differences between groups that interact in what can be described as a collaborative manner, and those that are cooperative.

Collaborative learning is described as taking place where students work towards "attaining shared understandings of meanings", such as when students engage with one another to achieve consensus in a group task (Dillenbourg et al., 1996, p. 204). Roschelle and Teasley (1995) describe collaboration specifically as "a coordinated, synchronous activity that is the result of a continued attempt to construct and maintain a shared conception of a problem" ( $p$. 70 ). While educators may set their classes to group tasks with this kind of social learning process in mind, students working as a group may not necessarily engage in collaborative methods. In contrast, they can end up dividing the work among participants so that each person is only responsible for part of the task (Roschelle \& Teasley, 1995). As such, instead of students being involved in collaborative learning, the task becomes a cooperative effort, where participation is based on individual labour rather than collective interaction between members.

Now that digital technologies are increasingly used in educational contexts, research has extended to computer supported collaborative learning (CSCL), promoting the ability to use technology to facilitate those beneficial social processes between students (Stahl, Koschmann, $\&$ Suthers, 2006). However, like face-to-face group interactions, collaboration is not something that will necessarily happen just by 
putting students and technology together. Productive CSCL depends on scaffolding of tasks and a pedagogical design of learning activities that invite collaboration through structuring of social interactions (Häkkinen \& Hämäläinen, 2012; Rienties et al., 2012).

Online technologies play a significant role in the Australian university experience (Baik, Naylor, \& Arkoudis, 2015). Higher education institutions have embraced the move to facilitating learning through digital technologies, predominantly by employing learning management systems (LMS) that provide a range of social technologies such as discussion forums, wikis, and blogs (Williams van Rooij, 2012). The socially-interactive affordances of the technology tools in a LMS are designed to create opportunities for improved learning experiences through student communication with peers and teachers (Keengwe \& Georgina, 2012). Though a LMS offers various tools for innovating online learning activities in higher education, the associated communication tools, such as discussion forums for providing information and asking questions, seem to be more popularly valued by instructors (Gruzd, Haythornthwaite, Paulin, Gilbert, \& del Valle, 2016). As such, the affordances of the tools provided can be neglected so that the LMS functions not as an interactive learning space, but as an information system to deliver content, and provide syllabus and assessment information (Godwin-Jones, 2012). This can result in students seeing the LMS as an information retrieval platform rather than an interactive space, let alone a platform for collaboration (Hrastinski \& Aghaee, 2012). A key factor, then, for a LMS to work more as a collaborative space with students involved in discussion activities is having instructor involvement to guide appropriate use (Klobas \& McGill, 2010).

More informal digital platforms may also be used for engaging students in group learning activities in the classroom, such as Facebook and Twitter (Tess, 2013). These sites can be used as an alternative to the LMS as these may be platforms that students are already comfortable using in their personal lives (Duncan \& Barczyk, 2015; Ellefsen, 2016). However, the educational use of these sites also has associated issues, such as possibilities for distraction and concerns around privacy (Flanigan \& Babchuk, 2015; Selwyn, 2016). Nevertheless, from the abundance of research available, it seems that regardless of whether educators incorporate digital technologies for learning with an institutional LMS or an open SNS, facilitating productive collaborative online learning requires careful planning. This has led researchers to call for institutional policies to encompass better training of educators in pedagogical use of online platforms (Manca \& Ranieri, 2017).

Though research has chiefly investigated the use of various social media applications for facilitating social learning conditions as organised by the institution or educator, there are also, albeit scarce, studies exploring digital technologies as employed by students around their activities of learning. Because Facebook has gathered such a large population of users, university students may use the platform for informal academic gratifications as well as social purposes (Lampe, Wohn, Vitak, Ellison, \& Wash, 2011). For example, university students' use of Facebook may extend beyond their personal social interactions to discussions of the university experience, and exchanges of practical and/or academic information (Adalberon \& Säljö, 2017; Lampe et al., 2011; Selwyn, 2009). For some students, this type of academic use stems from a personal use of social media, and as such, the interactions that take place are often with ties that are already known to the learners (Selwyn, 2009). But university students may also use Facebook as a platform for linking to new social ties by joining university Facebook groups (DeAndrea, Ellison, LaRose, Steinfield, \& Fiore, 2012). 
Yet, between the institutional teacher-managed space of an educationally-used SNS like Facebook, and the personal online space that students occupy, a 'third' space that blurs the boundaries between academic and social life can also exist (Aaen \& Dalsgaard, 2016). In studies by Deng and Tavares (2013, 2015), students who organised Facebook groups outside the institutional LMS, used the platform not only to share information and academic support, but also to socialise with other members of the class. Another example of a blurring between social and academic online spaces are large Facebook groups set up by university students to chat about their course for academic and social support (Adalberon \& Säljö, 2017; Stirling, 2014). These 'third' space uses of Facebook can also be created on a smaller scale by the need for students to communicate to complete group work assignments (McAliney, 2013). Indeed, in a study by Henderson et al. (2015), almost $90 \%$ of students were using Facebook or other SNSs to work with other students in their courses.

The impact of this movement of group work from face-to-face interactions to an online activity has received little research attention. For international students, the peer social interactions that grow out of activities such as working on an assignment together can assist in easing adjustment to a new cultural and educational context (Cruickshank et al., 2012). Research of international students' uses of digital technologies for learning suggests that students from different language backgrounds to the host destination may face challenges with online communication due to language difficulties (Habib, Johannesen, \& Leikny, 2014). Yet, using digital technologies for learning can also allow more time to compose and understand communication in asynchronous online environments, as well as provide greater space for confidence in sharing opinions (Erichsen \& Bolliger, 2011). At this stage, though, there is little research on the impact of educational uses of social media on international students making social connections (Sleeman, Lang, \& Lemon, 2016). In contrast, research on international students highlights that personal use of digital platforms such as SNSs are important during an overseas study experience, not only for maintaining contact with home culture connections (Mikal, Yang, \& Lewis, 2015), but also for establishing points of contact with the host culture (Forbush \& Foucault-Welles, 2016). However, international students still face difficulties establishing social capital with host country ties even with online contact (Lee \& Ranta, 2014). For this reason, participation in group work, which students are now more often choosing to conduct via a digital platform, may be one opportunity where international students are able to develop new connections through sustained interactions with peers.

With studies of international students' personal uses of social media pointing to its importance for maintaining social capital during studies abroad, and little research exploring students' use of informal digital platforms in educational contexts for social connection, this prompts the research question guiding this study:

How does the use of informal social media for group work impact on international students' perceptions of social connection?

\section{Method}

This research sought to illuminate understanding of the educational implications of social media use for international students from their own perspective, and thus interviews were conducted as an appropriate self-report method to generate qualitative data. With the purpose of the study being to explore a range of student experiences and perceptions, the method of thematic analysis was chosen to identify patterns across participants' narratives.

Participants were recruited from English language academic preparation courses, prior to their commencement in degree courses at $\mathrm{La}$ 
Trobe University in 2016. From volunteer sampling, a total of 12 males and 14 females took part in the study, mostly aged between 18 and 25 , with only four students over the age of 25 . The participant group included 14 students starting an undergraduate degree and 12 starting a postgraduate degree. Students were all from language backgrounds other than English and came from a range of countries. The largest cohorts of students in the study came from China, India and Vietnam, with eight, six, and four students respectively, which corresponds to Australia's three largest international source markets for higher education at the time (Department of Education and Training, 2016). The remaining students came from Middle Eastern countries, such as Iran, Iraq and Jordan, but also Indonesia, Russia and Argentina.

Interviews were conducted at two points during the participants' first semester, at around weeks 4-5 and then again at weeks 8-10. The interview questions were semi-structured to investigate students' educational uses of social media and perceptions of connection to classmates. Recordings of interviews were then transcribed, pseudonyms were assigned for student names, before a coding process was conducted. As appropriate to an exploratory study, an inductive coding technique was used, where themes emerge from the data (Onwuegbuzie \& Combs, 2010). After each interview, initial perceptions of key points were noted. To formalise this coding procedure, NVivo software was then used to enter transcripts and create codes based on initial impressions. In this first coding process, other codes were also added through a more in-depth reading of transcripts. As such, in this first stage, a 'sensing' of themes was accomplished (Boyatzis, 1998). After an iterative process of coding, the Google Drive mind mapping application was then used to create a visualisation of the codes to complete the final step of the thematic analysis process of defining and naming themes (Braun \& Clarke, 2006). Finally, individual interview data for each participant was examined again to look for similarities and differences between the cases to explore associated variables between themes.

\section{Findings}

The major theme identified in this study was that students were using informal social media platforms to conduct group assignments. Apart from one postgraduate student, all other participants in this study were involved in doing group assignment/s that had been set by their teacher for assessment. Assignment types varied according to the participant's field of study, but most commonly they were in the form of a presentation or a written report. In their first semester at university, there were very few students negotiating only a single group assignment as part of their assessment across four subjects, with the majority involved in multiple concurrent and/or consecutive groups. In addition, out of the 25 students completing group assignments, only one was not using a social media application to complete the task. The other 24 students reported predominantly using applications such as Facebook and WhatsApp to interact with their peers to complete their group assignments.

From the ways that students described their use of social media to conduct their group assignments, three sub-themes were identified: organisational, cooperative and collaborative. Firstly, for a few students, they had decided to use a social media application to simply organise meetings where students would then interact face-to-face about the assignment. However, in the majority of group assignment situations, students used digital platforms in varying degrees to complete the group task. In addition to the organisational interactions previously mentioned, the two themes of cooperative and collaborative interactions emerged in regard to how students interacted online to complete the learning task. 
The theme of using social media to take a cooperative approach to the group task was identified by a range of students. In these situations, students reported using their chosen online platform to interact to divide work among the group members for ultimate compilation, with little mention of interactions to discuss understandings of the task together. For example, Nilesh, a student from India, was involved in a Facebook group to coordinate a group report, but he indicated that each student completed their work for their assignment individually, before collating their parts for final submission.

The third theme was using social media in a collaborative manner to complete group assignments. Many of these participants were also involved in groups that divided their assignment into separate parts, but they highlighted that they engaged in discussion of the task in more collaborative terms. For example, Phuong, a student from Vietnam, described how her group used Facebook to divide what each member would do for the assignment, but also to "discuss about what is best, what is not good for the assignment". Similarly, Zara, a student from China, discussed how the Facebook conversations of her group focused on deciding who wanted to do a particular part of the assignment, but also included talking about "some strategies" to complete it. Some students talked about these collaborative interactions in terms of having an opportunity to engage instructional assistance from other members about the content of their work. For instance, Phuong explained that if she did not understand what to do for her part, she would ask on Facebook and her group members would give her advice. Her group members would also share their individual parts to have an opportunity to gain feedback on their work on "which is ok, which is not ok".

Reported online collaborative interactions in group assignments also included linguistic help where domestic students were part of the international student's group. For example,
Daniel, from China, had help from his group with writing structure and grammatical issues, as he noted "a lot of grammar mistakes and structure is not good, but they will tell me how to write down, your structure and avoid some grammar mistakes". Carrie, another student from China, also discussed her group members giving her instructional advice and language assistance by suggesting how to write her part of the essay, as well as checking the grammar and vocabulary of her part. A few students also described their online learning interactions including discussions of content. For instance, Benam, from India, used his Facebook groups to debate disagreements about individual answers in their assignments, as well as providing explanations to Benam's questions about content he did not understand.

From these cooperative and collaborative online group work interactions, students had various perceptions of connections to classmates with both themes of perceptions of connection and disconnection emerging. A number of students using social media for group assignments described feeling a connection to their group work members. For example, Crystal, a student from China, described her perception of her Facebook group as "support, connected with other students". This connection for learning was echoed by other students who had chosen to use an online platform, such as Facebook to interact with classmates for an assignment. Daniel was another undergraduate student from China who spoke of feeling a connection to one of his two Facebook groups. Though the connection did not move beyond his academic life, he remarked "I think we are friends, but we don't communicate with each other for (sic) after class". Though Daniel did not interact with his Facebook group work participants beyond what was necessary for his academic work, his use of the word 'friends' indicates that he felt a connection existed between them within the learning context. Other students communicated stronger perceptions of a connection to classmates, such as Benam, who described his 
Facebook groups, "I just made friends to do my academic work, but now we make friends with each other. We go out, have a good time". Likewise, Carrie maintained that the students in her Facebook group had moved from a formal classmate relationship to "we are friends now".

These students who discussed experiences of making online connections with classmates were associated with collaborative interactions that supported students' completion of academic work. Like Crystal's indication that the online learning connections that she had made with classmates provided her with support "about the workshop questions, about the assignments or how to do that", the other students who perceived a learning connection also pointed to connections involving discussions of learning which gave them assistance with academic work. For instance, Daniel described only feeling that he was 'friends' within the academic context with one of his two Facebook groups: the group that discussed with him how to improve his academic writing ability. The other two students noting a classmate connection, Benam and Carrie, also worked with their Facebook groups to discuss their understandings of the content for their assignments.

The second theme to emerge in international students' reports was a lack of connection, or disconnection, in their use of social media for group assignments. In students' experiences of these situations, instead of the educational use of a social media platform facilitating connection to classmates, it was used in ways that created boundaries between them. In many of these situations, international students' perceptions of disconnection were associated with the use of social media to facilitate a minimum of interaction or only observation of, but not participation in, online group assignment discussion with classmates.

Many students spoke of a perception of disconnection in their work on group assignments where they used the online platform for organising a strictly cooperative approach to working on the task. Nilesh said of the cooperative interactions in his Facebook groups: "everyone will talk only about the group work and the assignment, that's it. No-one say hello, no-one say hi". Gabriella, an undergraduate student from Argentina, similarly complained that her Facebook groups insisted on using the online platform to divide their tasks and complete the work individually without having to meet up with each other. She felt that this impacted on her so that she felt disconnected from her classmates, saying "this is just send the assignment, so you don't interact with the other one". Samaira, a postgraduate student from India, also had a similar experience where students in her group used WhatsApp to discuss division of their presentation assignment into individual parts with one final meeting to rehearse. In Samaira's group with two other international students and an Australian, she noted "we don't know each other that much, so we are just talking about the work we have to do". As such, in terms of connection, Samaira felt "We are not that much socially connected ... someone have to take the initiative to maintain the social group, but no-one is interested".

Yet, reports of more collaborative discussions with group work members did not necessarily correlate to international students feeling that they had made connections with classmates. Two undergraduate students from China, Zara and Jacinta, indicated that interactions in their Facebook groups with domestic students had not facilitated a feeling of connection for them. Zara and Jacinta each described their Facebook groups as engaging in collaborative interactions about their assignment. Zara highlighted that her group discussed "strategies" for gaining instructional advice to complete the task, while Jacinta described her group talking about the answers to questions for their marketing assignment. When asked about their perceptions of connection to these classmates, Jacinta was emphatic about the lack thereof, saying "No, no, no. I think except study, there is 
no other connect (sic) between us". Zara was more evasive, but she indicated a disconnection from her group members in her reluctance to interact with them, stating, "I usually won't talk to them through Facebook. It's also a little bit difficult to chat to them in class." Zara's answer may indicate that though the students in her Facebook group were engaged in collaborative interactions, Zara herself was only an observer, and therefore may not have felt connected to the others in the group.

\section{Discussion}

The use of a social media platform, such as Facebook or WhatsApp, for educational interactions with peers can be seen both positively and negatively regarding international students developing a sense of connection to new peers. While the students in this study interacted with their classmates for group assignments, the online interactions they were engaged in did not always lead to "attaining shared understandings of meanings" (Dillenbourg et al., 1996, p. 204). In contrast, for some students their group work consisted of individual efforts of cooperation (Roschelle \& Teasley, 1995). Along with the already documented benefits of collaborative group learning over cooperative interactions (Johnson \& Johnson, 2009), these types of exchanges can benefit a sense of connection to classmates as well.

In collaborative interactions with classmates in their Facebook or WhatsApp groups, some international students noted a sense of connection, either for learning support or friendship. Here the use of social media opened up a space between the academic and social lives of students, in a 'third' space that combined aspects of both, similar to the groups in Aaen and Dalsgaard's (2016) study. In these situations, the online conversations that students participated in for a group assignment could also offer international students connections to ease academic adjustment in the same way as face-to-face group work situations, as seen in Cruickshank et al.'s (2012) research. On the other hand, other students who engaged in only minimal interaction with peers in a cooperative effort to complete their group assignment did not express feelings of connection to classmates.

Yet, collaborative interactions in online group work was not always consistent with feeling a connection. Where the two students from China who described collaborative interactions in their online groups also conveyed a sense of disconnection from their classmates, it is possible that language difficulties may have contributed to a lack of interaction in the collaborative discussions taking place in the group on behalf of the participant themselves (Habib et al., 2014). Therefore, as an observer of collaborative group discussions, the participant may not have developed a sense of connection to peers.

Though educators may include group assignments in the curriculum to encourage collaborative interactions among students, when students move into informal learning spaces, they may not necessarily interact in ways that teachers intended. For this reason, it is important that educators are mindful of the possibility that students can conduct participation in a group assignment with minimal interaction through a cooperative group effort. Therefore, developing teaching and learning strategies to promote student interaction in online spaces can benefit the international student experience (Cruickshank et al., 2012). This calls for institutions to invest in training educators how to use online platforms for better student engagement (Manca \& Ranieri, 2017), which can lead to classroom modelling of digitally-mediated collaborative interactions (Häkkinen \& Hämäläinen, 2012) to improve students' participation in group assignments. This would be of benefit to all students to enhance communication practices, but particularly in providing students with language difficulties ways to interact with classmates on group 
assignments that can then assist their social interaction. Furthermore, providing more strategic guidance around how to collaboratively interact in online spaces can assist students in developing connections to peers, which can enhance social connections as they commence their studies.

\section{Conclusion}

Interaction with peers plays an important role in assisting adjustment to a new cultural context for international students (Cruickshank et al., 2012). Now that social media is increasingly used for managing personal social networks for many students, how the educational use of these services impact on international students for social connection also deserves attention. This study suggests that collaborative online interactions between classmates can be promoted rather than cooperative exchanges so that students may gain both cognitive and social benefits.

This study offers thematic data from a small group of international students at a single university, but larger scale studies across multiple locations are also needed to further investigate these themes. From more in-depth investigations, it will be possible to develop further understandings of the contexts in which social media can play a role in connecting students. This knowledge can then contribute to the design of strategies for the productive use of digital technologies for educational engagement and the improvement of the international student experience.

\section{References}

Aaen, J., \& Dalsgaard, C. (2016). Student Facebook groups as a third space: Between social life and schoolwork. Learning, Media and Technology, 41(1), 160-186. doi:10.1080/17439884.2015.1111241

Adalberon, E., \& Säljö, R. (2017). Informal use of social media in higher education: A case study of Facebook groups. Nordic Journal of Digital Literacy, 12(04), 114128. doi:10.18261/issn.1891-943x-2017-04-02 ER

Baik, C., Naylor, R., \& Arkoudis, S. (2015). The First Year Experience in Australian Universities. Findings from two decades 1994-2014. Retrieved from https://melbourne-

cshe.unimelb.edu.au/ data/assets/pdf file/0016/1 513123/FYE-2014-FULL-report-FINAL-web.pdf

Boyatzis, R. (1998). Transforming Qualitative Information. Thematic analysis and code development. Thousand Oaks: SAGE Publications.

Braun, V., \& Clarke, V. (2006). Using thematic analysis in psychology. Qualitative Research in Psychology, 3(2), 77-101. doi:10.1191/1478088706qp063oa

Cruickshank, K., Chen, H., \& Warren, S. (2012). Increasing international and domestic student interaction through group work: A case study from the humanities. Higher Education Research \& Development, 31(6), 797-810. doi:10.1080/07294360.2012.669748

DeAndrea, D. C., Ellison, N. B., LaRose, R., Steinfield, C., \& Fiore, A. (2012). Serious social media: On the use of social media for improving students' adjustment to college. The Internet and Higher Education, 15(1), 1523. http://dx.doi.org/10.1016/j.iheduc.2011.05.009

Department of Education and Training. (2016). Research snapshot: International student numbers 2015. Retrieved from https://internationaleducation.gov.au/research/Res earch-

Snapshots/Documents/Student $\% 20$ Numbers $\% 2020$ 15.pdf

Deng, L., \& Tavares, N. J. (2013). From Moodle to Facebook: Exploring students' motivation and experiences in online communities. Computers \& Education, 68(0), 167-176. http://dx.doi.org/10.1016/j.compedu.2013.04.028

Deng, L., \& Tavares, N. J. (2015). Exploring university students' use of technologies beyond the formal learning context: A tale of two online platforms. Australasian Journal of Educational Technology, 31(3), 313-327. https://doi.org/10.14742/ajet.1505

Dillenbourg, P., Baker, M., Blaye, A., \& O'Malley, C. (1996). The evolution of research on collaborative learning. In P. Reimann \& H. Spada (Eds.), Learning in humans and machines: towards an interdisciplinary learning science (pp. 189-211). Oxford: Pergamon.

Duncan, D. G., \& Barczyk, C. C. (2015). The Facebook effect in university classrooms: A study of attitudes and sense of community using an independent measures control group design. American Journal of Management, 15(3), 11-22.

Ellefsen, L. (2016). An investigation into perceptions of Facebook-use in higher education. International 
International students' transition to university: Connection and disconnection in online group work interactions

Journal of Higher Education, 5(1), 160-172. https://doi.org/10.5430/ijhe.v5n1p160

Erichsen, E. A., \& Bolliger, D. U. (2011). Towards understanding international graduate student isolation in traditional and online environments. Educational Technology, Research and Development, 59(3), 309-326. https://doiorg.ez.library.latrobe.edu.au/10.1007/s11423-010$\underline{9161-6}$

Flanigan, A. E., \& Babchuk, W. A. (2015). Social media as academic quicksand: A phenomenological study of student experiences in and out of the classroom. Learning and Individual Differences, 44, 40-45. http://dx.doi.org/10.1016/j.lindif.2015.11.003

Forbush, E., \& Foucault-Welles, B. (2016). Social media use and adaptation among Chinese students beginning to study in the United States. International Journal of Intercultural Relations, 50, 1-12. http://dx.doi.org/10.1016/j.ijintrel.2015.10.007

Godwin-Jones, R. (2012). Challenging hegemonies in online learning. Language, Learning \& Technology, 16(2), 413.

Gruzd, A., Haythornthwaite, C., Paulin, D., Gilbert, S., \& del Valle, M. E. (2016). Uses and gratifications factors for social media use in teaching: Instructors' perspectives. New Media \& Society, doi:10.1177/1461444816662933

Habib, L., Johannesen, M., \& Leikny, Ø. (2014). Experiences and challenges of international students in technology-richlLearning environments. Journal of Educational Technology \& Society, 17(2), 196-206.

Häkkinen, P., \& Hämäläinen, R. (2012). Shared and personal learning spaces: Challenges for pedagogical design. The Internet and Higher Education, 15(4), 231-236. http://dx.doi.org/10.1016/i.iheduc.2011.09.001

Henderson, M., Selwyn, N., Finger, G., \& Aston, R. (2015). Students' everyday engagement with digital technology in university: Exploring patterns of use and 'usefulness'. Journal of Higher Education Policy and Management, 37(3), 308-319. doi:10.1080/1360080X.2015.1034424

Hrastinski, S., \& Aghaee, N. (2012). How are campus students using social media to support their studies? An explorative interview study. Education and Information Technologies, 17(4), 451-464. doi:10.1007/s10639-011-9169-5

Janssen, J., Kirschner, F., Erkens, G., Kirschner, P. A., \& Paas, F. (2010). Making the black box of collaborative learning transparent: Combining process-oriented and cognitive load approaches. Educational Psychology Review, 22(2), 139-154. https://doi.org/10.1007/s10648-010-9131-x

Johnson, D. W., \& Johnson, R. T. (2009). An educational psychology success story: Social interdependence theory and cooperative learning. Educational
Researcher,

$38(5)$, https://doi.org/10.3102\%2F0013189X09339057

Keengwe, J., \& Georgina, D. (2012). The digital course training workshop for online learning and teaching. Education and Information Technologies, 17(4), 365379. doi:10.1007/s10639-011-9164-x

Klobas, J. E., \& McGill, T. J. (2010). The role of involvement in learning management system success. Journal of Computing in Higher Education, 22(2), 114-134. http://dx.doi.org/10.1007/s12528-010-9032-5

Lampe, C., Wohn, D. Y., Vitak, J., Ellison, N. B., \& Wash, R. (2011). Student use of Facebook for organizing collaborative classroom activities. International Journal of Computer-Supported Collaborative Learning, 6(3), 329-347. http://dx.doi.org/10.1007/s11412-011-9115-y

Lee, K., \& Ranta, L. (2014). Facebook: Facilitating social access and language acquisition for international students? TESL Canada Journal, 31(2), 22. https://doi.org/10.18806/tesl.v31i2.1175

Manca, S., \& Ranieri, M. (2017). Implications of social network sites for teaching and learning. Where we are and where we want to go. Education and Information Technologies, 22(2), 605-622. doi:10.1007/s10639015-9429-x

McAliney, P. J. (2013). How undergraduate students use social media technologies to support group project work. (Doctoral dissertation.), New York University, New York, United States.

Mikal, J. P., Yang, J., \& Lewis, A. (2015). Surfing USA: How internet use prior to and during study abroad affects chinese students' stress, integration, and cultural learning while in the United States. Journal of Studies in International Education, 19(3), 203-224. doi: $10.1177 / 1028315314536990$

Onwuegbuzie, A. J., \& Combs, J. P. (2010). Emergent data analysis techniques in mixed methods research: A synthesis. In A. Tashakkori \& C. Teddlie (Eds.), SAGE handbook of mixed methods in social \& behavioral research (pp. 397-430). Los Angeles: SAGE.

Rienties, B., Giesbers, B., Tempelaar, D., Lygo-Baker, S., Segers, M., \& Gijselaers, W. (2012). The role of scaffolding and motivation in CSCL. Computers \& Education, 59(3), 893-906. http://dx.doi.org/10.1016/j.compedu.2012.04.010

Roschelle, J., \& Teasley, S. D. (1995). The construction of shared knowledge in collaborative problem solving. In C. O'Malley (Ed.), Computer supported collaborative learning (pp. 69-97). Berlin, Heidelberg: Springer Berlin Heidelberg.

Selwyn, N. (2009). Faceworking: Exploring students' education-related use of Facebook. Learning, Media and Technology, 34(2), 157-174. doi:10.1080/17439880902923622 
Selwyn, N. (2016). Digital downsides: exploring university students' negative engagements with digital technology. Teaching in Higher Education, 21(8), 1006-1021. doi:10.1080/13562517.2016.1213229

Sleeman, J., Lang, C., \& Lemon, N. (2016). Social media challenges and affordances for international students: Bridges, boundaries, and hybrid spaces. Journal of Studies in International Education, 20(5), 391-415. doi:10.1177/1028315316662975

Stahl, G., Koschmann, T., \& Suthers, D. (2006). Computersupported collaborative learning. In K. Sawyer (Ed.), The Cambridge handbook of learning sciences (pp. 409-426). Cambridge: Cambridge University Press.

Stirling, E. (2014). "We use Facebook chat in lectures of course!" Exploring the use of a Facebook group by first-year undergraduate students for social and academic support. In M. Kent \& T. Leaver (Eds.), An education in Facebook?: Higher education and the world's largest social network (pp. 23-31). New York: Taylor \& Francis.

Tess, P. A. (2013). The role of social media in higher education classes (real and virtual)-A literature review. Computers in Human Behavior, 29(5), A60A68. doi:10.1016/j.chb.2012.12.032

Tinto, V. (1997). Classrooms as communities: Exploring the educational character of student persistence. The Journal of Higher Education, 68(6), 599-623. doi: $10.2307 / 2959965$

Williams van Rooij, S. (2012). Open-source learning management systems: a predictive model for higher education. Journal of Computer Assisted Learning, 28(2), 114-125. doi:10.1111/j.13652729.2011.00422.x

Zhao, C.-M., \& Kuh, G. (2004). Adding value: Learning communities and student engagement. Research in Higher Education, 45(2), 115-138. doi:10.1023/B:RIHE.0000015692.88534.de 